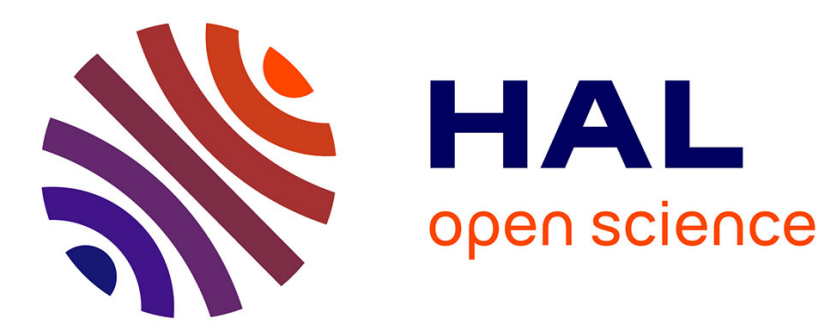

\title{
Paris and London superimposed: urban seeing and new political space in Dicken's A Tale of Two Cities
}

Sara Thornton

\section{To cite this version:}

Sara Thornton. Paris and London superimposed: urban seeing and new political space in Dicken's A Tale of Two Cities. Etudes Anglaises, 2012. hal-02063169

\section{HAL Id: hal-02063169 \\ https://hal.science/hal-02063169}

Submitted on 27 Sep 2019

HAL is a multi-disciplinary open access archive for the deposit and dissemination of scientific research documents, whether they are published or not. The documents may come from teaching and research institutions in France or abroad, or from public or private research centers.
L'archive ouverte pluridisciplinaire HAL, est destinée au dépôt et à la diffusion de documents scientifiques de niveau recherche, publiés ou non, émanant des établissements d'enseignement et de recherche français ou étrangers, des laboratoires publics ou privés. 


\section{PARIS AND LONDON SUPERIMPOSED: URBAN SEEING AND NEW POLITICAL SPACE IN DICKEN'S A TALE OF TWO CITIES}

Sara Thornton

Klincksieck | «Études anglaises »

2012/3 Vol. 65 | pages 302 à 314

ISSN 0014-195X

ISBN 9782252038468

Article disponible en ligne à l'adresse :

https://www.cairn.info/revue-etudes-anglaises-2012-3-page-302.htm

Distribution électronique Cairn.info pour Klincksieck.

(C) Klincksieck. Tous droits réservés pour tous pays.

La reproduction ou représentation de cet article, notamment par photocopie, n'est autorisée que dans les limites des conditions générales d'utilisation du site ou, le cas échéant, des conditions générales de la licence souscrite par votre établissement. Toute autre reproduction ou représentation, en tout ou partie, sous quelque forme et de quelque manière que ce soit, est interdite sauf accord préalable et écrit de l'éditeur, en dehors des cas prévus par la législation en vigueur en France. Il est précisé que son stockage dans une base de données est également interdit. 
Sara THORNTON

\section{Paris and London superimposed: urban seeing and new political space in Dicken's A Tale of Two Cities}

This article will be looking at how space is seen, constructed and made meaningful in A Tale of Two Cities and how this brings out some key questions about Dickens, the two cities he loved and his political position as a writer. Our first focus will be on the technique of seeing or showing from above, that is, seeing panoramically or in terms of a scene performed publicly which the eye can encompass. If we look closer at this super-envisioning and supervision and its correlative desire to grasp new space, it appears to be linked to an act of superimposition, that is, the laying of one topography over another, one history or present of the city space over another. In A Tale of Two Cities Paris and London are strangely mixed and interwoven, we see them stereoscopically that is as a fusion of two images. I would argue that Dickens's visions of London and Paris and the complex overlaying of one on the other show not only a desire to experiment with lines of sight and geographical and ideological positions but is perhaps an attempt to rethink British politics. This shifting of the gaze to encompass another urban reality might be seen to run counter to critiques of $A$ Tale of Two Cities which have seen the latter as a reactionary and chauvinistic stance on the French revolution.

Cet article tente d'établir un lien entre la perception et la construction de l'espace urbain dans A Tale of Two Cities et le positionnement politique d'un texte qui a quelquefois été qualifié de réactionnaire et même francophobe. Le texte de Dickens démontrerait, au contraire, un désir de comprendre l'énergie et la force de la révolution, et de surplomber Paris afin d'observer clairement le fonctionnement d'une ville qui est l'inverse d'un Londres statique et sombre, reflet d'un système archaïque. Si l'œil du narrateur surveille et surplombe Paris, Londres n'offre que des vues partielles, le fond d'une ville labyrinthique sans ligne de fuite. Ce conte fantastique de deux villes opère également une superposition stéréoscopique de Paris et de Londres, résultat du désir d'imaginer un Londres amélioré, libéré, revu et corrigé par l'énergie de l'Europe révolutionnaire, mais aussi par la modernité et l'efficacité du projet haussmannien.

Dickens was a regular visitor to France and a declared Francophile. He even lived there for short periods, was received at the home of Victor Hugo in 1847 in the place des Vosges (then Place Royale) and met many of

Sara THORNTON, Paris and London superimposed: urban seeing and new political space in Dickens's A Tale of Two Cities, ÉA 65-3 (2012): 302-314. (C) Klincksieck. 
the great writers of the day including Théophile Gauthier and Alexandre Dumas. Dickens crossed the channel 68 times between 1862 and 1865 alone (Tomalin). His attachment to France is perhaps further shown by his decision to install his beloved mistress, Ellen Ternan, at Boulogne and Paris. He chose France as the place he would live with her away from the constraints of British society. His mind seems to have been moving between the two cities, as it was between two societies, two women, two political and aesthetic regimes. France afforded Dickens a view of another reality and a means of negotiating his own mental tensions and divisions. We are in the realm of what Guy Debord has called a "psychogeography," the latter, according to Merlin Coverley, being a "tale of two cities," an urban experience linked to political opposition which challenges the "official representation of the city" (Coverley 12). Cutting across official routes and reinstating marginal and forgotten areas was a daily experience and indeed practice for Dickens in his walking, performing this depth and doubleness as he traversed London which became a palimpsest of times and ideas like Freud's vision of Rome (Freud).

This article will be looking at how space is seen, constructed and made meaningful in A Tale of Two Cities and how this brings out some key questions about Dickens, the two cities he loved and his political position as a writer. Our first focus will be on the technique of seeing or showing from above, that is, seeing panoramically or in terms of a scene performed publicly which the eye can encompass. Dickens's other novels mostly favour the domestic interior and the confined view of the London street or court. Only Martin Chuzzlewit (1844) and Barnaby Rudge (1841) offer broader vistas. In A Tale, the city, particularly Paris, is shown to us in particular ways involving "super" visions or "supervisions," that is, panoptic visions, which imply a desire to supervise and even control. These are mixed of course with more intimate scenes at street level of particular groups and individuals. If the scenes from above reflect an engagement with a broad sweep of history, then the close street-level scenes take us back into bourgeois realism and the family unit (more common in depictions of London and typical of incipits like that of Great Expectations). These contrasting standpoints reflect what Michel de Certeau has called the scopic and gnostic gaze or drive involved in the vision from above versus the blinder, more intimate sphere of the "everyday," down in the fleshly reality of the street (De Certeau 91-92). The bird's eye view brings out Dickens's "super-visory" role as a creator of new space. He becomes a textual or writerly Baron Georges Haussman or Joseph Bazalgette, the two redesigners of Paris and London of the nineteenth-century, reinscribing the city with new meaning. Like the character Saccard in Émile Zola's La Curée (1895), who divides up the city of Paris with his knife (following the lines begun by Haussmann) from a restaurant high above Paris on the Butte Montmartre, Dickens uses his pen to redraw the topographies of London and Paris. We will see that this is 
an attempt to observe politics, create historical vision and engage with the idea of the mass.

If we look closer at this super-envisioning and supervision and its correlative desire to grasp new space, it appears to be linked to an act of superimposition, that is, the laying of one topography over another, one history or present of the city space over another. In A Tale of Two Cities Paris and London are strangely mixed and interwoven, we see them stereoscopically that is as a fusion of two images. The stereoscope at the time was an optical instrument and also a popular visual toy popularized by Oliver Wendell Holmes and the feature of an extensive display at the Victoria and Albert Museum in London. It created for viewers a new hybrid, three-dimensional effect and an illusion of depth and tangibility unknown before. I would argue that Dickens's visions of London and Paris and the complex overlaying of one on the other show not only a desire to experiment with lines of sight and geographical and ideological positions but is perhaps an attempt to rethink British politics. This shifting of the gaze to encompass another urban reality might be seen to run counter to critiques of $A$ Tale of Two Cities which have seen the latter as a reactionary and chauvinistic stance on the French revolution or a celebration of British conservative gradualism.

Dickens tells a tale and "tells" the city; he chooses a telescopic vision which can oscillate from one side of the channel to the other and which therefore brings out a multiple seeing. He is discursive and indeed dialectical in his descriptions of Paris and London and creates a third term in his constant shuttlings back and forth: that "term" is a city which is neither Paris nor London but a dream city like that envisioned by Sydney Carton at the end of the novel. Carton's words suggest the following dream: if only Paris and London could be mixed, their topography, politics and history melted together, then what a perfect city might emerge. In writing A Tale of Two Cities, Dickens creates a crucible in which to transcend the boundaries of nation and state to body forth a new city in new imaginary space, a sort of "Nowhere" or indeed an Erewhon (Butler, Morris) which is a more desirable somewhere, the best of both cities.

\section{Super-visions}

This iconic novel is at the same time central to the work of Dickens-one of the most filmed novels of Dickens, and has at times been the most read $^{1}$ —and also eccentric to his work, different from

1. Jones, McDonagh, and Mee describe it as "an icon of British national identity" and Carton's guillotine speech and the opening paragraph as "some of the most frequently quoted, misquoted and mimicked of Dickensian aphorisms" (Jones, McDonagh and Mee 4-5). 
any other novel. It is the least "Dickensian" of his novels since it leaves the stifling closure of the British city and takes us across the channel to another cultural and political scape. One need only compare the vistas of Paris and the French provinces which appear in the novel with the cramped and inward-turning atmosphere of the London scenes. In the French scenes (nineteen chapters are set in Britain while twenty-four are set in France) we are aware of an eminently Romantic turn closer to Scott's Waverley (1814), than to the Victorian novel, which reveals a fascination with passionate popular movements and with the violent crowd. Dickens was creating something different from Bleak House (1853) and the other London-bound novels where the complexities of the street and domestic interior are the focus.

If we consider the different modes of seeing the city in the nineteenth-century we might make the following claim: if social reformers, such as Henry Mayhew and Edwin Chadwick, went down into street and consider the detail of water, mud, dress, quality of skin, hair, bone and flesh as well as the detail of walls, floors and household objects, then city reformers like Haussmann and Bazalgette tended to remain above their grand schemes and divide-up of the city using a broad bird's eye vision. Their writings describe the reordering of urban space as if they were placing brush strokes on a canvas with lofty detachment. Yet radical political thinkers like Friedrich Engels combine the two stances and shuttle between a global vision and the detail of the streets. Dickens tends to favour such a combination in A Tale of Two Cities and often chooses a panoramic vision for Paris, allowing us to see the streets and their interconnections, while London tends to be obscured and reduced to confined spaces. In A Tale we "see" Paris and only divine London. De Certeau gives the following analysis of such divided seeing starting with the view from above; he establishes a useful opposition between the panoptic aerial viewpoint of the mapmaker, which renders the city legible and comprehensible, and the walker's perception of space at ground-level. In the latter case, this involves a rhetoric of walking through a city which inevitably remains illegible and mysterious:

[From high up the agitation of the city] is momentarily arrested by vision. The gigantic mass is immobilized before the eyes. It is transformed into a texturology in which extremes coincide.... When one goes up there, he leaves behind the mass that carries off and mixes up in itself any identity of authors or spectators. An Icarus flying above these waters, he can ignore the devices of Deadalus in mobile and endless labyrinths far below. His elevation transfigures him into a voyeur. It puts him at a distance. It transforms the bewitching world by which one was "possessed" into a text that lies before one's eyes. It allows one to read it, to be a solar Eye, looking down like a God. The exaltation of a scopic and Gnostic drive: the fiction of knowledge is related to this lust to be a viewpoint and nothing more. (De Certeau 91) 
He then takes us down into the maze of streets:

The ordinary practitioners of the city live "down below," below the thresholds at which visibility begins. They walk-an elementary form of this experience of the city; they are walkers, Wandersmänner, whose bodies follow the thicks and thins of the urban "text" they write without being able to read it. These practitioners make use of spaces that cannot be seen; their knowledge of them is as blind as that of lovers in each other's arms. The paths that correspond in this intertwining, unrecognized poems in which each body is an element signed by many others, elude legibility. It is as though the practices organizing a bustling city were characterized by their blindness. The networks of these moving, intersecting writings compose a manifold story that has neither author nor spectator, shaped out of fragments of trajectories and alterations of spaces: in relation to representation, it remains daily and indefinitely other. (De Certeau 92)

Scenes of Paris offer a series of arenas and theatres for action, space designed for a mapping out politics. The "parvis" of the Hôtel de Ville, the carrefour where the child is run down by the Marquis, the area around the Bastille where the revolutionaries collect, divide and disperse, all become so many scenes in which mass action or the action of the masses can be seen.

In the context of $A$ Tale, De Certeau's distinction needs some adjustment since the mapped view from above involves a human presence absent in De Certeau's vision. In the Paris scenes the crowds are seen not in their detail but as displacements and manoeuvres as on a battle field. The London-based crowd scenes in A Tale of Two Cities remain very different from the Parisian crowd scenes. The funeral of the spy Roger Cly in Book the Second is a slow-moving procession from Fleet Street to Old Saint Pancras church and functions on a series of individual actions rather than on a collective rising and organisation. Dickens's uses the term of "mob" and speaks of the crowd which "melted away" (164). A cumbersome and ill-assorted caravan, the procession only serves to create a sense of the directionless and sourceless desire of the crowd which sees indistinctly and works on "fragments of trajectories" to take up De Certeau's expression. As the raison d'être of the cortège disappears the crowd follows a series of different paths according to the whims of individual participants who suggest various forms of vandalism (tearing up the area railings or impeaching passers by, 164). We have no clear vision of their movement through London.

In contrast, the climactic scenes in the chapter "Echoing footsteps" (Book the Second, Chapter 21) suggest a sort of geolocalized tracing of a crowd united in its design and described as a sea or an ocean (224) with "billows" and "spray" (227) and even "a raging flood" (228). There is a sense in which we are watching a flow of water through channels (a replay of the wine escaping in rivulets down sundry gutters and grooves in the Book the First, chapter 5 "The Wine Shop"). Tides, ebbs and flows are mentioned as if the crowd has become, literally, a 
mass movement, working as one single flow of water. Even the sounds it emits and the words shouted become a collective element and no longer a matter of individual production: we see that "bushels of words" (233) move with the crowd as it surges through the city. All this is viewed by an all-seeing eye which encompasses the scene and moves above it yet with it. In the London mob scene the narrator is down with the participants with a partial view of its actions as if there are no clear interconnections between the boroughs of London and their streets.

If the Dickens Novel mostly presents the individual or family group within the city, in A Tale, that individual is part of a crowd but also part of an even larger general movement of history and ceases simply to evolve in his or her own narrow conjuncture of time. The view from above (which is sometimes only a slight elevation) is thus not only the result of a desire to produce an urban mapping of the movement of people at a time of strife but it is an expression of a desire to see history and time in a vaster temporal scape. Let us consider the panoramic and most un-Dickensian opening of the novel. "Book the First" with its biblical opening title "Recalled to Life" begins in this way:

\begin{abstract}
It was the best of times, it was the worst of times, it was the age of wisdom, it was the age of foolishness, it was the epoch of belief, it was the epoch of incredulity, it was the season of Light, it was the season of Darkness, it was the spring of hope, it was the winter of despair, we had everything before us, we had nothing before us, we were all going direct to Heaven, we were all going direct the other way-in short, the period was so far like the present period, that some of its noisiest authorities insisted on its being received, for good or for evil, in the superlative degree of comparison only.
\end{abstract}

We might first ask who is speaking? The use of "we" is very indeterminate and appears not to be nation-based but implies that the speaker might be both French and British, a fusion of Carton and Darnay, or perhaps more generally, a European, who is partaking of a broader experience. It might also be seen as producing a Hegelian vision in which national boundaries are transcended to allow the experience of a sort of geist or spirit of the times. "It was the best of times, it was the worst of times..." implies a distance in time but also a collective stance even before we reach the word "us" and "we." The word "times" implies an experiencing of a certain moment by a certain group, a vast group, not an individual. The conflicting adjectives suggest an attempt to come to terms discursively with an unreadable and enigmatic moment in history which the writer grasps at by looking back from a distance and as part of a group of persons experiencing those "times". The definite article translates a consensus of opinion producing that moment as a recognisable entity, a particular moment registered by more than just the narrator as memorable and remarkable ("an age," "an epoch," "times," "season," "spring and winter"). We find the use of the past tense in which the "moment," or the "times," is definitively gone by, and can 
now be seen and analysed by those who participated in them and have an angle, a purchase on them. "We" are shown to be acting in those faraway times, and to be participating in the on-going moment: "we had" and "we were all going." There is a cinematic vision of that past participation and action-involvement. It is a temporal bird's eye view, but also an injunction since there is an attempt to "show," to designate by saying "Look, this was us."

In comparison, the opening paragraph of Bleak House has a diminished sense of "we" (only a remnant is left in the sentence "And would it not be marvellous."), and there is no sense of the collective. The narrator is a detached and cynical voice who observes the alienation of individuals in the street as a series of separate atoms colliding and aggressing each other, a truly Schopenhauerian vision of mankind as a collection of warring individuals. We are confronted with a street-level vision of mud and crowds quite ununited by what Elias Canetti has called the "spark" or ignition of collective desire. A crowd, according to Canetti, does not become a crowd until its members lose their "burdens of distance," differences of rank, status and property. Canetti calls this moment of equality "the discharge," and the crowd is not a crowd until the discharge takes place. The promptings of a demagogue can be the occasion for a crowd to gather, but it is not those promptings which makes the crowd a crowd. Rather it is the loss of the fear of being touched, which leads to the loss of the burdens of distance and freedom from command. For him, part of the burden of distance is made up of the "stings of command accumulated in every individual." These are the psychological effects in individuals of the commands coming from all the sources of authority to which men are subject. The revolutionary crowd thus comes together to rid itself of the accumulated stings of command which its members are no longer capable of getting rid of on their own (Canetti in McClelland 296-99).

The opening paragraph of $A$ Tale thus seems to suggest just such an ignited "we" which is utterly absent in most of the opening pages of Dickens's novels from Oliver Twist (1837) to Bleak House (1853) and Great Expectations (1861). An acting crowd is implied here, very rare in Dickens, as well as the idea of a mass experience. Georg Lukács, following Hegel, saw the French Revolution and the later Napoleonic wars as the first contact many ordinary people had with politics and that for the first time history became a mass experience. Dickens's proletariat does not usually form and storm but remains singular, eccentric, divided into particular examples of quirky behaviour. John Bowen explains well the mass history and mass experience as defined by Lukács in his Hegelian account of the rise and fall of the historical novel. Lukács claimed that A Tale of Two Cities shows a "modern privateness in regard to history" (Lukács in Bowen 115) which opposed friendship and individual relations to the claims of millions and posited a redemptive resolution rather than political or truly tragic energy. We are asked to care 
particularly about a handful of people and not to cleave so closely to the millions. The ending is a private solution to revolutionary violence "narcissistic, idealized, exemplary, testamental, sacrificial, redemptive, expiatory act" (Bowen 117). ${ }^{2}$

Dickens is in some way participating in a reflection on the centrality of the individual and his or her liberty and the opposing power of the collective. In A Tale he seems to recognise the debate at mid-century over the nature and desirability of mass democracy which included John Stuart Mill's On the Nature of Representative Government (1851) and On Liberty (1859). The latter was concerned with the defence of a sacrosanct individual in the face of a majoritarian tyranny, by a fictive and imagined "one" against an imposing majority. This conflict comes down to the famous lines in which Mill says that "If all mankind, minus one, were of one opinion, mankind would be no more justified in silencing that one person than he, if he had the power, would be justified in silencing mankind" (Mill 76). The only justification, says Mill, for "interfering with the liberty or action of any of their number, is self protection" (Mill 68). It could be said that A Tale, in its negotiation between the close-up on the individual and its apprehension of the mass, is a huge negotiation between "I" (the paramount individual seen at close quarters) and "we" (the collective, the collegiate and the mass movement seen at a distance).

We might consider briefly Friedrich Engels' opening of his chapter "The Great Towns" in The Condition of the Working-Class in England in 1844 as an example in which we see a similar insistence on an urban scape seen from a distance (from the boat which Engels took from the beginning of the Thames estuary up to Westminster).

A town, such as London, where a man may wander for hours together without reaching the beginning of the end, without meeting the slightest hint which could lead to the inference that there is open country within reach, is a strange thing. This colossal centralisation, this heaping together of two and a half millions of human beings at one point, has multiplied the power of this two and a half millions a hundredfold; has raised London to the commercial capital of the world, created the giant docks and assembled the thousand vessels that continually cover the Thames. I know nothing more imposing than the view which the Thames offers during the ascent from the sea to London Bridge. The masses of buildings, the wharves on both sides, especially from Woolwich upwards, the countless ships along both shores, crowding ever closer and closer together, until, at last, only a narrow passage remains in the middle of the river, a passage through which hundreds of steamers shoot by one another; all this is so vast, so impressive, that a man cannot collect himself, but is lost

2. Lukács sees A Tale of Two Cities as a failed historical novel because of its petit-bourgeois humanism and failure to embrace the broader sweep of history (Lukács). Baldridge and Friedman explore the tensions between the individual and the mass in A Tale of Two Cities (Baldridge; Friedman). 
in the marvel of England's greatness before he sets foot upon English soil. (Engels 68)

This is a description of a perfect and functioning city which is perhaps akin to the one Sydney Carton envisages as he dreams of the new Paris to come after the turmoil of the Revolution. Yet it also goes on to cover a ground-level chaos akin to the first paragraph of Bleak House. The view from above suddenly swoops down and jars uncomfortably with the reality of being on foot within the labyrinth of London, the miserable streets behind the commercial and industrial façade.

But the sacrifices which all this has cost become apparent later. After roaming the streets of the capital a day or two, making headway with difficulty through the human turmoil and the endless lines of vehicles, after visiting the slums of the metropolis, one realises for the first time that these Londoners have been forced to sacrifice the best qualities of their human nature, to bring to pass all the marvels of civilisation which crowd their city; that a hundred powers which slumbered within them have remained inactive, have been suppressed in order that a few might be developed more fully and multiply through union with those of others. The very turmoil of the streets has something repulsive, something against which human nature rebels. (Engels 68)

We are both seeing politics from above as a spatial landscape and from below as confused and fragmented. Dickens's writing is very like Engels in the opening paragraph of A Tale of Two Cities since it looks broadly both geographically and temporally and as if from a distance at the city space of London. Both texts bring out the ambiguity of best and worst, great and small. In later chapters, Dickens gives London to the reader in terms of individual streets, bourgeois or working class interiors and private concerns Friedrich Engels expresses the isolation of the individual in the following way:

The brutal indifference, the unfeeling isolation of each in his private interest becomes the more repellant and offensive, the more these individuals are crowded together, within a limited space. And, however much one may be aware that this isolation of the individual, this narrow self-seeking is the fundamental principle of our society everywhere, it is nowhere so shamelessly barefaced, so self-conscious as just here in the crowding of the great city. The dissolution of mankind into monads, of which each one has a separate principle, the world of atoms, is here carried out to its utmost extreme. (Engels 69)

Like Engels, Dickens juxtaposes within one novel the struggle of the individual and at the same time a dream of the collective, of an amassing and organisation and blending of the one with the many. To do this he must shuttle between two cities: often dark and confined and slow in London (the funeral procession) or bourgeois domestic and protectedalmost bucolic like the square the Manettes live in. In Paris, he changes tack to provide a sense of panorama and the sweep of history and like 
Engels provides us with contrasting visions of the city. We might now fruitfully look beyond the idea of a binary alternation and consider a more intimate fusion of two alternative urban topographies.

\section{Superimpositions}

In oscillating between France and Britain and between close-up and panorama, Dickens opens up the possibility of a mechanism of superimposition. He creates a complex cityscape which is also an ideal. Most importantly, Paris and London are seen each through the prism of the other (a dream of London through an idealised although threatening Paris). We might firstly list the ways in which both historical and political events and ideas overlay or underpin A Tale of Two Cities: the scenes of rioting and setting fire in Barnaby Rudge and its depiction of the no-Popery riots is present within the frenzied scenes of collective destruction in Paris, the texts of reformers and revolutionaries such as Mayhew and Engels lie under some of the prose descriptions of Paris while the virulent discourse of Dickens against the Indian Mutiny of 1857 is clearly present in the horror of the violence of the grinding stones and blood-baths of the Parisian street. We might also mention a peculiar stereoscopic effect which emerges in the novel and calls to the attention of the reader the geographical lay-out of power of each city. Paris is seen as a plan, theory, model or blueprint, while London is shown to be the result of a system, of the empirical, the gradualist additions of empirical experience rather than having been submitted to a master plan be it topographical or political. London in A Tale is shown to be an addition of boroughs, a sort of bricolage.

Dickens creates a mental map to navigate the unknown waters of London, and the city is dogged by a consciousness of other realities which, to quote Coverley, "exposes the psychical connectivity of landscapes" by a "fictional and poetic reworking" (Coverley 16). If William Blake celebrates the spiritual city behind London, the new Jerusalem behind the chartered streets, then Paris is a kind of potential and changed London, a "magical realm behind our own" (Coverley 16). Critics have seen $A$ Tale as a warning against complacency and lack of serious governmental reform and Dickens himself warned of this danger in several letters (Jones 58). Like Marx, Engels and indeed Carlyle, Dickens sought to shatter the dead fossilized political forms which London represented for him.

Paris thus becomes a space of swift movement and action. The storming of the Bastille and taking of Foulon in front of the Hôtel de Ville is an example of his. A certain modernity and efficiency comes through in the descriptions of Paris closer to Dickens's knowledge of the new Haussmann Paris which he visited so often. Paris was far from revolutionary in the late 1850's but very pleasant and being improved all the time. Dickens did not visit the poor areas of Paris at that time 
but dined outside in the Tuileries or Champs-Élysées. As Jones tells us, Dickens had little knowledge or cognisance of the poverty of the Faubourg Saint-Antoine, but huge knowledge of "New Paris". As Dickens writes in "A little dinner in an Hour" in All the year Round in 1869 he spent much of his time in Paris "pleasantly breakfasting in the open air in the garden of the Palais-Royal or the Tuileries, pleasantly dining in the open air in the Elysian Fields, pleasantly taking my cigar and lemonade in the open air on the Italian boulevards towards the small hours after midnight" (Jones 14). Much of the material for scenes of poverty in the Saint-Antoine scenes came from knowledge of the East End of London. In one article of 1855 "Paris Improved" which appeared in Household Words a journalist collaborator of Dickens suggests that London should be modelled on the improvements of Paris. If London was in administrative and jurisdictional chaos, then Paris was already improved and W.H. Wills describes it as "wonderfully improving" about rue de Rivoli and even "a stone and sculptured paradise" (Jones 14).

London was thus seen as atavistic and constrained in comparison with the vision of new Paris which Dickens had been experiencing first-hand. A Tale of Two Cities moves between Paris and London in a dialectical fashion, comparing and critiquing each with and against the other and producing a sublation in the form of a Paris which is also a strangely functioning and commercial London-a sort of ideal Regents Street allowing Dickens to express the commercial energy of Haussmann's new Paris through the swiftness of the revolutionary city. An acceleration is shown in the scenes in Paris as against the "stoppage" of British political life epitomized in Bleak House where ancient laws block any attempt at change. The latter is clearly present in the brilliant second chapter of $A$ Tale in which mud and fog impede the horses and show the uphill struggle of life, a sense of something powerful being held back as well as the very Orwellian servitude of the horses. If mud and fog are paradigms for this stagnation, then the movement of the crowd through the cityscape is a paradigm for constitutional change and flexibility.

Rather than a disciplinary eye keeping the city under surveillance as D.A. Miller has suggested in The Novel and the Police, Dickens has often been depicted as walking with people down in the street, brushing against them so to speak, interested in the social change the city space can produce. The oceanic feeling of the crowd scenes implies a desire to be free of the heavy aristocratic and borough-bound nature of London and the immovable class system. If narratives of urban catastrophe, revolution or disaster, make a city momentarily strange-what Coverley calls the "revolutionary cessation of the everyday" (38), then we might ask if Dickens's depiction of Paris during the revolution was a means of exorcising London's repressed politics. The representations 
of the city imply a fantasy of real action impossible in London's chartered streets and its legal system seen as slow-moving and sluggish like the Thames. Such change was only possible in an "elsewhere" where political space had been left open. The confined streets of London are overlain by the parvis of Paris-a space of protest but also, possibly, a forum of exchange. Dickens's engagement with Paris pushed this imaginative potential further and allowed him to reconsider Britain and its governmental and even aesthetic regime by superimposing one city onto another. Paris becomes a ghostly alternative to London and a possibility of renewal. Similarly, the future of Haussmann's fast moving boulevards and commercial organisation lies ghostly over revolutionary Paris.

\author{
Sara THORNTON \\ Université Paris Diderot \\ LARCA EA 4214
}

\title{
Bibliography
}

Baldridge, Cates. "Alternatives to Bourgeois Individualism in A Tale of Two Cities." Studies in English Literature 30 (1990): 633-54.

Bowen, John. "Counting On: A Tale of Two Cities". Eds. Colins Jones, Josephine McDonagh, Jon Mee. Charles Dickens, A Tale of Two Cities and the French Revolution. Basingstoke and New York: Palgrave Macmillan, 2009.

Butler, Samuel. Erewhon. [1872]. Harmondsworth: Penguin, 2006.

Carlyle, Thomas. The French Revolution. [1837]. New York: Random House, 2002.

Cook, Susan. "Season of Light and Darkness: A Tale of Two Cities and the Daguerrean Imagination.” Dickens Studies Annual 42 (2011): 237-60.

Coverley, Merlin. Psychogeography. Harpenden: Pocket Essentials, 2010.

De Certeau, Michel. "Marches dans la ville". L'Invention du quotidien; arts de faire. 1. Paris : Gallimard, 1990.

-. The Practice of Everyday Life. 1. Trans. Steven Rendall. Berkeley: U of California P, 1984.

Dickens, Charles. A Tale of Two Cities. [1859]. Harmondsworth: Penguin, 2003.

Engels, Friedrich. The Condition of the Working-Class in England in 1844. [1892]. London: Penguin, 2009.

Freud, Sigmund. Civilisation and its Discontents. [1930]. Trans. James Strachey. New York: Norton, 2010.

Friedman, Barton R. “Antihistory: Dickens' A Tale of Two Cities.” Fabricating History: English Writers on the French Revolution. Princeton, NJ: Princeton UP, 1988.

Jones, Colins, Josephine McDonagh and Jon Mee, eds. Charles Dickens, A Tale of Two Cities and the French Revolution. Basingstoke and New York: Palgrave Macmillan, 2009.

Lodge, David. "The French Revolution and the Condition of England: Crowds and Power in the Early Victorian Novel." The French Revolution and British Culture. Eds. Ceri Crossley and Ian Small. Oxford: Oxford UP, 1989. 
Lukács, Georg. The Historical Novel. Trans. Hannah and Stanley Mitchell. Harmondsworth: Penguin, 1969.

McClelland, J. S. The Crowd and the Mob. From Plato to Canetti. London: Unwin, 1989.

Mill, John Stuart. On Liberty. [1869]. Ed. Gertrude Himmelfarb. Harmondsworth: Penguin, 1974.

Miller, D. A. The Novel and the Police. Berkeley CA, and London: U of California P, 1988. Morris, William. News from Nowhere (or an Epoch of Rest). [1890]. News from Nowhere and Other Writings. Harmondsworth: Penguin, 1993.

Tomalin, Claire. Charles Dickens: A Life. London: Viking, 2011. 